\begin{tabular}{|l|l|l|}
\hline \multicolumn{2}{|c|}{ PublisherInfo } \\
\hline \hline PublisherName & $:$ & BioMed Central \\
\hline \hline PublisherLocation & $:$ & London \\
\hline \hline PublisherImprintName & $:$ & BioMed Central \\
\hline \hline
\end{tabular}

\title{
Dying without mitochondrial gene expression
}

\begin{tabular}{|l|l|l||}
\hline \multicolumn{2}{|c||}{ ArticleInfo } \\
\hline \hline ArticleID & $:$ & 4031 \\
\hline \hline ArticleDOI & $:$ & $10.1186 /$ gb-spotlight-20010330-02 \\
\hline \hline ArticleCitationID & $:$ & spotlight-20010330-02 \\
\hline \hline ArticleSequenceNumber & $:$ & 102 \\
\hline \hline ArticleCategory & $:$ & Research news \\
\hline ArticleFirstPage & $:$ & 1 \\
\hline \hline ArticleLastPage & $:$ & 2 \\
\hline \hline & $:$ & RegistrationDate : 2001-03-30 \\
ArticleHistory & $:$ & OnlineDate \\
\hline \hline ArticleCopyright & $:$ & BioMed Central Ltd2001 -03-30 \\
\hline \hline ArticleGrants & $:$ & \\
\hline \hline ArticleContext & $:$ & 130592211 \\
\hline \hline
\end{tabular}




\section{Jonathan B Weitzman}

Email: jonathanweitzman@hotmail.com

Dysfunction of the mitochondrial respiratory chain is involved in diabetes, heart failure, neurodegeneration and aging. In the March 27 Proceedings of the National Academy of Sciences USA, Wang et al. described experiments to determine the effect of loss of the mitochondrial transcription factor A (Tfam) gene on cell death (Proc Natl Acad Sci USA 2001, 98:4038-4043). Tissue-specific knockout of the murine Tfam gene, which regulates transcription of mitochondrial DNA, caused mitochondrial cardiomyopathy associated with increased cardiomyocyte apoptosis in vivo. Germline mutation of the Tfamgene caused embryonic lethality, and evidence for increased apoptosis in day embryos at embryonic day 9.5. These results suggest that increased apoptosis may contribute to the pathology of human disorders that result from mitochondrial DNA mutation.

\section{References}

1. Proceedings of the National Academy of Sciences USA, [http://www.pnas.org]

2. Dilated cardiomyopathy and atrioventricular conduction blocks induced by heart-specific inactivation of mitochondrial DNA gene expression.

3. Mitochondrial transcription factor $\mathrm{A}$ is necessary for mtDNA maintenance and embryogenesis in mice. 